\title{
Perspective of PMO in Compliance of Madurese Ethnic Tuberculosis Patient in Tapal Kuda Regions
}

\author{
Irma Prasetyowati ${ }^{1}$ \\ Faculty of Public Health \\ Universitas Jember \\ Jember, Indonesia \\ irma_prasetyowati.fkm@unej.ac.id
}

\author{
Ida Srisurani Wiji $\mathrm{A}^{2}$ \\ Faculty of Medicine \\ Universitas Jember \\ Jember, Indonesia \\ rani.fk@unej.ac.id
}

\author{
Akhmad Haryono ${ }^{3}$ \\ Faculty of Humanities \\ Universitas Jember \\ Jember, Indonesia \\ aharyono.sastra@unej.ac.id
}

\begin{abstract}
Tuberculosis cases in Indonesia are ranked at the top 10 in the world, in which East Java Province is at the 2nd highest tuberculosis cases from 33 provinces in Indonesia. In East Java, the problem of severe tuberculosis occurs in such Tapal Kuda regions as Jember, Bondowoso and Lumajang. The Case Notification Rate in each of these areas is $137 / 100.000,65 /$ 100.000 population and $74 / 100.000$ population respectively. The strategy to ensure patient recovery is the use of short-term antiTB drug alloys and the application of drug control called the Direct Observed Treatment Short Course (DOTS). In the treatment of tuberculosis there is very possible the occurrence of drop out treatment or drop out. Cases of drop out have a higher risk of tuberculosis recurrence, anti-tuberculosis drug resistance, and can transmit the infection to others. Based on the data from the World Health Organization (WHO) in 2013, the resistance of tuberculosis germs resulted from non-adherence treatment of 12.6\%. The Drug Controller (PMO) plays an important role in reminding, monitoring, and motivating $\mathrm{TB}$ patients to remain obedient to treatment. This study aims to determine the perspective of PMO in compliance to treatment of Madurese ethnic tuberculosis patients in Tapal Kuda regions. The method used is triangulation and verification using qualitative approach. The results of the study showed that according to the PMO the factors that influenced the treatment of Tuberculosis patients during the treatment period were the lack of medical expenses, the low of patient's confidence in the treatment, the lack of access to health service, and the lack of motivation of the patient to make good treatment and therefore there needs to be proactive support from PMO and family as well as ongoing comprehensive and proactive socialization related to the awareness raising of the patient about the importance of tuberculosis treatment and the improvement of patient understanding related to TB treatment.
\end{abstract}

keywords-tuberculosis; PMO; obedience; madurese ethnic; tapal kuda

\section{INTRODUCTION}

Tuberculosis is an infectious disease caused by germs from the mycobacterium group that is mycobacterium tuberculosis. Tuberculosis cases in Indonesia are ranked at the top 10 in the world [1]. Globally in 2014 Southeast Asia (29\%) and Africa (26\%) accounted for the largest number of TB cases, and the second continent was India with $75 \%$ mortality. India, China and South Africa are the countries with the highest burden of accounting $\mathrm{Tb}$ of 1.98 million, 1.4 million, and 0.5 million respectively. Based on WHO Global Tuberculosis Control 2012, Indonesia rose from the fifth rank to the fourth after India, China and South Africa. Of course the problem of Tuberculosis (TB) control is increasing and Indonesia has an incidence rate of about 450,000 new patients per year or incidence rate of 187 / 100,000 inhabitants as well as Pulmonary TB mortality rate of 65,000 per year or 27 / 100.000 population.

To achieve cure requires treatment compliance for every lung TB patient. The development of anti-tuberculosis drugs has revolutionized in the 1950s, which led to the reduction of $\mathrm{TB}$ case deaths, and since then both have developed and developing countries have begun to leave hospitalization. Worldwide experience has shown that TB patients no longer need to be isolated from other hospital patients as well as from the community with the introduction of short chemotherapy and rapid sterilizing effects of rifampicin in the 1970s [2]. Strategies to ensure patient recovery include the use of short-term anti-TB drug alloys and the application of drug control or DOTS (Direct Observed Treatment Short-course). Although alloys used are good but if 
the patient does not get regular treatment then generally the results are disappointing [3-4]. To achieve the patient recovery requires compliance with medication accompanied by supervision in taking medication.

Tuberculosis drug supervisor plays an important role in realizing government's program “ Indonesia without Tuberculosis in 2020". A cross sectional approach study about tuberculosis was conducted by. The purpose of this study was to provide any information about the correlation of drug supervisor activeness with motivation and medication compliance. It said that drug supervisor has to actively motivate patient with tuberculosis in order to increase their medication adherence. Health care unit could enhance the drug supervisor activeness and patient's motivation in order to prevent the spread of tuberculosis [5].

The stop TB strategy 2006-2015 focused on six strategic areas with an aim to reduce TB prevalence and mortality by $50 \%$ relative to 1990 levels. The centerpiece of this strategy was to expand and enhance access to quality TB diagnosis and treatment, addressing MDR-TB and TB/HIV coinfection, strengthening healths systems, enganging public and private providers, empowering patients, and promoting research [6].

One risk factor of $\mathrm{TB}$ is influenced by transmissions rate(acid resistant bacilli level). The adult with positive acid resistant bacilli exhibits more infectious than negative patients. It shows $65 \%$ the transmission higher in patient with positive acid resistant bacilli, $26 \%$ in patient with negative acid bacilli, and $17 \%$ in patient with positive value of thoracic roentgenv[7].

\section{MATERIAL AND METHOD}

The approach of this research is qualitative with the characteristics of the researcher as a key instrument, emphasizing the process, and data analysis is inductive. This research method uses triangulation and verification. Researchers conducted explorations of data related to tuberculosis disease in three areas, namely Jember, Lumajang and Bondowoso. The findings of quantitative and qualitative data were analysed qualitatively.[8-10] The targets in this study were the PMO of the drop out TB patient and the recovered TB patient. In this study the number of informants as many as 4 informants with category 2 informants is the PMO of people drop out TB and 2 informants are PMO TB patients who have healed.

Data collection in this research is done by 3 ways, that is in-depth interview by using interview guide and data collection got from Health Department, Public Health Centre and Internet. The process of interpretation of research is related to two dimensions: text and social context are combined as a single unit of analysis. The next step is to combine the results of analysis, social understanding and social context with theoretical framework in categorization to gain a new understanding of the phenomenon.

\section{RESULT AND DISCUSSION}

PMO is an abbreviation of the Drug Swallowing Supervisor. The duties of a PMO include monitoring TB patients to take medication regularly until treatment completes, encouraging patients to seek treatment regularly, reminding patients to check for sputum at a predetermined time, providing counseling to family members of TB patients who have symptoms suspicious TB suspects to immediately go to the health care unit [11]. According to the PMO, there are several things that can affect the compliance of TB treatment patients as mentioned below.

\section{A. Self Motivation Patient}

PMO explained that one of the factors that can improve patient TB treatment compliance is self-motivation of patients who are strong to recover. This is obtained from the results of in-depth interview as follows:

" ndak ada.. kalo yang lain, banyak yang ndak diminum nak. Ndak sampe habis. Saudara saya lho. Kerjanya itu kana pa, bank kreditan mingguan itu, sampe bolong paru-parunya nak. Itu Cuma minum berapa kali kata ibuknya, trus wes total ndak ngambil. Obat gratis yang disini itu ndak diambil selama 6 bulan. Lek bapak.e ndak nak. Sampe wadah.e didekek wedi onok kontrol.an teko pak budi. Ndak.. demi Allah nak kepingin sembuh. Polane sek duwe anak cilik iku tanggungane iku. Yo masalah sembuh ndak sembuh kan Allah sing nganu ya.. wong namanya usaha lah,.. kata bapak itu kan usaha. Manusia itu kalo ndak usaha, mosok Allah itu langsung nyembuhno kan (There is no other. If other patients, many do not take medication till finished. My brother who works as a weekly credit bank officer, his lungs are hollow. His mother said he only takes medication few times, after he does not take at all. The free medication available here has not been taken for 6 months. But his father does not do the same. I check the drug again, afraid there is a control from Mr. Budi. For God's sake, I want to be recovered because I still have a small child. The problem of being recovered or not God's business. It is just the effort. If we don't try, is it possible that God will immediately recover us").

The results of the interviews explain that the recovered patients have a strong motivation to be recovered from TB disease. In addition support PMO which is a member of his family becomes additional motivation for TB patients to recover from the disease. This result is in line with a study who stated that the role of a poor PMO is 3.013 times to cause the patient to disobey sputum checks in the final phase of treatment rather than with a candidate with a good PMO role [12]. In addition, social support by PMO in the form of emotional support increases motivation to people with pulmonary tuberculosis to recover from illness [13]. 
In the otherwise, a significant difference between the degree of knowledge of groups of patient and the groups of family relatives before and after the intervention was indicated, with a higher increase in family mix directly observed treatment shot-course (PFM-DOTS) group than in family based DOTS (FB-DOTS) group ( $p<0,001)$. In PFMDOTS group $100 \%$ of the patients, and in the FB-DOTS group $86,6 \%$ of the patients followed the recommended drugs regiment. According to the treatment recommendations by the World Health Organization for appropriate implementation of DOTS project combating TB, it seems the PFM-DOTS implementation is a more suitable method with greater effects on correct way to care and treatment of tuberculosis patients [14].

\section{B. $\quad$ Cost of treatment}

According to the PMO, the cost of treatment is a matter that affects the compliance of TB patient treatment. This is because patients can not afford the cost of treatment. This is evidenced by the results of in-depth interviews as follows:

"ngecek pole dhe' remma hasilla senika geruwa cak en mbak Watik. Engghi pas ta' abeli kan obengnga sobung kan kodhu sedia obeng pole" (I check again how the result. Bu Watik said the result is like this and so on. I do not come back because there is no money anymore. I must have money).

Based on the statement, it is known that the first problem faced by PMO related to patient compliance treatment is financial problem. This should not be a problem, since the government has provided free treatment programs to all TB patients until the patient is cured. This proves that the patient's lack of understanding of the treatment procedure that the TB patient must undergo.

Poverty is both cause and consequent of tuberculosis. A study from [15] proved that patient and household costs for TB care are potentially catastrophic even where services are provided free-of-charge. There is an urgent need to implement strategies for TB care that are affordable for the poor. Of 452 patients enrolled, majority were male $55 \%$, and rural residents $79 \%$, with a mean age of 34 years old. Median direct treatment cost was $\$ 36$ per patient. Indirect prediagnostic and treatment costs were $\$ 416$, or $79 \%$ of total patients costs. The median total costs of TB care per household was $\$ 592$; corresponding to $37 \%$ of median annual household income pre TB.

Most patients reported having to borrow money $(47 \%)$, sell assets $(9 \%)$, or both $(32 \%)$ to cope with the cost of care. Following an episode of TB, household income reduced increasing the proportion of household classified as poor from $54 \%$ to $79 \%$. Before TB illness, independent predictors of household poverty were; rural residence (adjusted odds ratio 2,8), HIV-positive status (adjusted odds ratio 4,8), and careseeking at a private facility (adjusted odds ratio 5,1). After TB care, independent determinants of household poverty were; younger age ( $\leq 35$ years old; adjusted odds ratio 2,4 ), male gender (adjusted odds ratio 2,1), and HIV-positive status (adjusted odds ratio 2,5).

Another study presented that the conceptual framework we used to define barriers and delays at the individual and provider/system levels at various time points along the continum of TB care. Individual-level barriers were defined to be financial (the direct or indirect costs of TB care, including costs of travel, diagnosis, and/or treatment as well as the opportunity costs of lost employment, compensation, or household work) [16].

\section{Patient's Trust in Treatment}

According to the PMO, patients who do not adhere to treatment have less confidence in TB treatment they live. TB patients are less confident with the outcome of treatment so that TB patients prefer not to continue treatment. It can be seen in the following results of the interview.

"mon epaenga' ya mare, tape ye tak oning polana pagghun (already reminded, but ya do not know anymore, he said that still no results from the treatment)"

"Mon cakna Bapak, masala laenna selaen tak cocok polana tadhe' se ngater (my husband said, other problems besides because it is not suitable also because no one to deliver)"

The results explain that the PMO has actually performed its role to remind and supervise taking medication, but tuberculosis patients feel that no outcome of treatment has been undertaken.

That has been strong correlation with the study from [17] the protective behaviors and intention to seek medical attention can be predicted by the Health Believe Model (HBM), especially by the component such as knowledge of $\mathrm{TB}$, perceived benefits of health behaviour, as well as certain demographic features(age, education, immigrant time). Improvement of the current helath education of migrant population is necessary.

\section{Access Transportation to Health Services}

The PMO explained that TB patients confessed if they did not obey medication because no one was taking them to take medicine at the nearest service facility. This can be seen in the following phrases.

"Mon cakna Bapak, masala laenna selaen tak cocok polana tadhe' se ngater. Pertama polana tak cocok, masala laenna polana tadhe' se ngater ngala' obat (My husband said that as well as it does not suit, other problems because nobody to deliver. First because it does not suit the treatment outcomes, and the other because nobody takes the medicine)"

The results explain that TB patients actually want to continue the treatment, but because no one who will take the drug since the TB patient is lazy to go to the health care facility. This can actually be prevented with the assistance of 
the PMO. So that later PMO will help to take the drug at the nearest health care facility.

Due to that fact, a study was conducted by [16], said the both barriers and delays in tuberculosis treatment caused by physical like distance, travel logistic, and/or acces to TB care facilities. Delay was defined as any time period between points along the $\mathrm{Tb}$ care pathway under our conceptual framework from symptom onset to TB treatment initiation. Although barriers and delays are highly interrelated, few studies assess the contribution of barriers to delay quantitatively. Women also experienced greater healthcare seeking costs due to transport or the need for an escort, which may impact a woman's autonomy in seeking care.

In Tak province, Thailand migrants and refugees from Myanmar navigate a pluralistic healthcare system to seek Tuberculosis care from a variety of government and nongovernmental providers. This multi-methods qualitative study examined acces to $\mathrm{TB}, \mathrm{TB} / \mathrm{HIV}$ and multidrug-resistant tuberculosis (MDR-TB) treatment with an emphasis on barriers to care and enabling factors. It found that refugees face fewer barriers to accessing TB treatment than migrants. For both migrants and refugees, legal status plays an important intermediary role in influencing the population's ability to access care and eligibility for treatment. Large geographical catchment area for migrants who seek TB treatment in Tak province that extends beyond provincial boundaries. Migrant participants described their ablity to seek care as linked to the financial and non financial resources required to travel and undergo treatment. Patients identified language of services, availability of free or low cost services, and psychosocial support as important health system characteristic that affect accessibility [18].

\section{E. Patient Motivation To Seek Well and Proper Medicine}

The PMO perspective that accompanies the patient's disobedient treatment explains that the perceived problems of PMO during accompanying patients are the lack of motivation of the patient to pursue good and correct treatment. This can occur when the lack of PMO role in providing emotional support such as additional motivation to encourage TB patients to be obedient to treatment. Research by Pare et al. (2013) explains that all TB patients who do not adhere to treatment have PMOs from family members, but they do not play a role well. Because of this poor role of PMO, more patients with pulmonary TB do not obey the treatment. The task as a PMO is mostly done in the form of a duty to remind the drugs and to monitor the swallowing of drugs, but the task of giving counselling to other family members is less [19].

\section{CONCLUSIONS}

Based on the results of this study, it can be concluded that in the perspective of PMO, compliance treatment of TB patients in the treatment is influenced by self-motivation of patients, medical expenses, patient confidence in the treatment, transportation access to health services, and motivation of the patients to seek the good and right treatment. Therefore, it is necessary for PMO and family to keep supporting and socializing the awareness-raising of the patient about the importance of tuberculosis treatment and the improvement of patient understanding related to TB treatment.

\section{ACKNOWLEDGMENT}

Thank you very much to Rector of University of Jember, Dean of Faculty of Public Health, University of Jember, and DPRM Ministry of Research Technology and Higher Education Indonesia for the support and assistance of this research realization.

\section{REFERENCES}

[1] Health Ministry of the Republic of Indonesia. National Guide of Tuberculosis. Jakarta: Directorate General of Disease Control and Environment Healthcare, 2014.

[2] WHO Geneva. Global Tuberculosis Report. Swittzerland: WHO Press, 2012.

[3] A. Asrifudin. Analysis of the Factors Related to the Successful Program of Lungs TB through DOTs Strategy at Working Areas of Publlic Health Centre, Caile, Kecamatan Ujung Bulu Kabupaten Bulukumba. (Thesis). Makassar: FKM Universitas Hasanudin, 2007

[4] Murtantiningsih dan B. Wahyono. The Factors Related to the Recovery of Patients with Lungs TB. Semarang. Public Health Journal, 2010; 6:44-50

[5] Bagaskoro, D.S, Sukartini T, and Hidayati L. 2016. Drugs Supervisor Activeness Correlated With Motivation And Tuberculosis Medication Adherence. Repository.unair.ac.id.

[6] Siroka A, Lonnorth K, and Ponce N. 2016. The impact of social protection on tuberculosis rates: a global analysis.

[7] Kementerian Kesehatan Republik Indonesia Direktorat Jendral Pengendalian Penyakit Lingkungan, 2013. Ringkasan Eksekutif Data dan Informasi Kesehatan Provinsi Sumatera Utara 2012.

[8] Miles, MB and Huberman, AM. Qualitative Data Analysis. Jakarta: UI Press; 1992.

[9] Moleong LJ. Qualitative Research Methodology. Bandung: Remaja Rosdakarya; 2001.

[10] Denzin NK, Lincoln YS. Handbook of Qualitative Research. New York: SAGE Publication; 2009.

[11] Health Ministry of the Republic of Indonesia. Regulation of Health Ministry of the Republic of Indonesia Number 67 Year 2016 about Tuberculosis Resolution. Jakarta: Health Ministry of the Republic of Indonesia; 2016.

[12] Sunarman, Krisnawati B. The Supervisor's Role in Medication and Obedience of Repeated Check-up of Sputum at Final Phase of Tuberculosis Treatment in Kabupaten Bangkalan. Jakarta: FKM UI. Thesis; 2012.

[13] Rachmawati T, Turniani L. The Influence of Social Support and Knowledge of TB Disease on the Motivation to Recover of the Patients with Lungs TB Who Take Medication at Public Health Centre. Surabaya. Bulletin of Health System Research, Vol.9, No. 3, July 2006: 134-141

[14] Sis Y,Rashedi J, and Jafarabadi M.2015.An Innovative Method to Enhance the Modified DOTS for TB Patients. Tanaffos. 2015: 14(3): 177-181.

[15] Ukwaja, K, Alobu, I, Igwenyi C, and Hopewell, P. 2013. The High Cost of Free Tuerculosis Services: Patient and Household Costs Associated with Tuberculosis care in Ebonyi state, Nigeria. Journals.plos.org. https://doiorg/10.1371/journal.pone.0073134. 
[16] PRESS, W, Gounder C, and Gupta, A. 2014. Barriers and Delays in Tuberculosis Diagnosis and Treatment Services: does Gender Matter? Tuberculosis research and Treatment.

[17] Li, ZT, Yang, SS, Zhang, XX, Fisher, EB, and Sun, XY. 2015. Complex relation among health believe model components in TB prevention and care. www.elsevier.com

[18] Tschirhart, N, Nosten, F, and Foster, A. 2016. Access to free or low cost tuberculosis treatment for migrants and refugees along the Tahiland-Myanmar border in Tak province, Thailand. Int Journal Equity Health. Biomed central.
[19] Pare AL, Amirudin R, and Leida I. Relationship among Work, PMO, Health Service, Family Support, and Discriminated Behavior of Patients with Lungs TB. Makassar: FKM Hasanudin University. Journal; 2013. 